\title{
Effect of Integrated Nutrient Management and Foliar Spray of Bioregulators on Growth and Yield of Okra
}

\author{
Khushboo Sharma $^{1 *}$, Archi Gupta ${ }^{1}$, Mukesh Kumar ${ }^{1}$, Manoj Kumar Singh ${ }^{1}$, \\ Sunil Malik ${ }^{2}$, Bijendra Singh ${ }^{2}$, S. P. Singh ${ }^{2}$ and Veena Chaudhary ${ }^{3}$ \\ ${ }^{1}$ Department of Horticulture, ${ }^{2}$ Department of Soil Science, Sardar Vallabhbhai Patel \\ University of Agriculture \& Technology, Meerut (U. P.), India \\ ${ }^{3}$ Department of Chemistry, Meerut College Meerut, UP, India \\ *Corresponding author
}

\section{A B S T R A C T}

Keywords

Integrated Nutrient

Management,

Bioregulators, Okra

Article Info

Accepted:

04 November 2020

Available Online:

10 December 2020
An experiment was conducted to examine the effect of integrated nutrients and foliar spray of brassinoides and salicylic acid on growth and yield of okra at HRC of SVPUAT, Meerut during the year 2019-20. The experiment was laid out in a factorial randomized block design with 9 treatments, three replications and 27 combinations. Among the treatments, plants fortified with 50 per cent RDF through inorganic fertilizer, 12.0 t/ha FYM, foliar application of brassinoids at $5 \mathrm{ppm}$ and salicylic acid $150 \mathrm{ppm}$ as bio-regulators was found most suitable in terms of yield and quality parameters of okra. However, nutrients supplied with 75 per cent RDF through inorganic fertilizer and 6.0 t/ha FYM, foliar spray of brassinoides $5 \mathrm{ppm}$ and salicylic acid $150 \mathrm{ppm}$ showed better performance in regarding the vegetative growth of okra.

\section{Introduction}

Okra is also known as Lady's finger, Bhindi in India and Gumbo in United States belongs to genus Abelmoscus on the basis of distinguished features of caduceus calyx and family Malvaceae. Okra said to be native of South Africa but widely cultivated in Tropical and Sub tropical regions of the world. It is an important vegetable grown for its tender fruits which are used as a vegetable in various ways. Nutritionally, okra is a good source of protein $2.10 \mathrm{~g}$, carbohydrate $8.20 \mathrm{~g}$, fat 0.20 g, fiber $1.70 \mathrm{~g}, \mathrm{Ca} 84.00 \mathrm{mg}, \mathrm{P} 90.00 \mathrm{mg}, \mathrm{Fe}$
$1.20 \mathrm{mg}, \beta$-carotene $185.00 \mu \mathrm{g}$, riboflavin $0.08 \mathrm{mg}$, thiamin $0.04 \mathrm{mg}$, niacin $0.60 \mathrm{mg}$, ascorbic acid $47.00 \mathrm{mg}$ Varmudy, (2011). Okra fruit is an excellent source of iodine which is necessary for the resistance against throat disease like goiter Chavan et al., (2007). Among the various factors affecting the growth and quality of okra, supply of balanced nutrition is very important. It is well reported that the growth and development of a plant, generally, depends on their judicious feeding and right time of application. Continuous application of imbalanced and excessive nutrients had led to decline in 
nutrient-use efficiency making fertilizer consumption uneconomical and producing adverse effects on atmosphere and groundwater quality, causing health hazards. Integrated nutrient management have been very useful approaches for increasing growth and yield of various horticultural crops (Kumar et al., 2013, Singh et al., 2013, Kumar, 2014 and 2014a, Phonglosa et al., 2015, Singh et al., 2014, Kumar, 2015, Singh et al., 2015, Kumar and Chaudhary, 2018, Singh et al., 2018, Tiwari et al., 2018 and 2018a Mohit et al., 2019, Priyanshu et al., 2019). INM approaches can increase crop yields as compared with conventional practices, increases water and nutrients use efficiency, economic returns to farmers and also improve vegetable quality and soil health (Kumar et al., 2018).

Plant growth regulators considered as natural or synthetic compounds and its low concentration can influence developmental and metabolic processes in plants Rademacher (2016). In crop production plant growth regulators promotes growth along with the longitudinal area, increase the number of branches, early flower initiation, fruit set, fruit quality and subsequently contributes towards higher production when applied at various concentration. Brassinoides are a class of polyhydroxy steroids that have been recognized as the sixth class of plant hormone which improve the resistance power in the plants against environmental stresses viz., water stress, salinity stress, low and high-temperature stress Rao et al., (2002) and crop productivity Vardhini et al., (2006) whereas, salicylic acid play an important role in plant growth, photosynthesis, transpiration, ion uptake, and transport in plants Popova et al., (1997) and Hayat et al., (2010). Earlier studies have demonstrated that a exogenous salicylic acid application, showed variable effects in various crops including an increase in yield of barley (El-Tayeb, 2005; Khodary,
2004; Yildirim et al., 2008;), more photosynthetic activity in wheat (Singh and Usha, 2003), higher total anthocyanin contents in Catharantus roseus (Hernandez and Vargas, 1997), inhibition of ethylene biosynthesis in rice leaves (Huang et al., 2004), and protection against biotic and abiotic stresses (Doares et al., 1995). Since limited information on the use of integrated sources of nutrients along with foliar applications of bio-regulators is available, and okra crops being the source of more income for many farmers of peri-urban areas, the present investigation was undertaken to optimize integrated doses of nutrients and foliar applications of bio-regulators for okra crop, through the evaluation of growth and fruit yield.

\section{Materials and Methods}

The experiment was conducted during the year 2019-20 at Horticultural Research Center (HRC) of Sardar Vallabhbhai Patel University of Agriculture and Technology, Meerut to study the effect of integrated nutrients and foliar spray of brassinoides and salicylic acid on growth and yield of okra. The experiment was laid out in a factorial randomized block design with 9 treatments and replicated thrice with 27 treatment combinations. Three levels of integrated nutrients like $\mathrm{R}_{0}$ as a Control, $\mathrm{R}_{1}$ (75\% RDF+6.0 t FYM/ha ) , $\quad \mathrm{R}_{2} \quad(50 \%$ $\mathrm{RDF}+12.0 \mathrm{tFYM} / \mathrm{ha}$ ) and three foliar applications of each growth regulators like Brassinoides viz. $\mathrm{B}_{0^{-}} 0 \mathrm{ppm}, \mathrm{B}_{1^{-}} 5 \mathrm{ppm}, \mathrm{B}_{2^{-}}$ $10 \mathrm{ppm}$ and Salicylic acid viz. $\mathrm{S}_{0^{-}} 0 \mathrm{ppm}, \mathrm{S}_{1}$ $100 \mathrm{ppm}$ and $\mathrm{S}_{2^{-}} 150 \mathrm{ppm}$. Before sowing of seeds, seeds were soaked in water overnight for early germination. During the experimentations, data were recorded in terms of growth and yield parameters by using standard methods. The data were statistical analysis as suggested by Gomez and Gomez, (1983). 


\section{Results and Discussion}

Effect of integrated nutrients and foliar spray of brassinoides and salicylic acid on vegetative growth of okra are presented (Table 1). The results showed that plants fortified with 75\% RDF and 6.0 tonne FYM/ha exhibited maximum plant height $(114.32 \mathrm{~cm})$, number of branches/plant (2.75), leaf area $\left(114.52 \mathrm{~cm}^{2}\right)$ and chlorophyll content $(1.69 \mathrm{mg} / \mathrm{g})$ which was statistically at par with application of 50\% RDF and 12.0 tonne FYM/ha whereas, minimum plant height $(107.69 \mathrm{~cm})$, number of branches/plant (1.55), leaf area $\left(91.03 \mathrm{~cm}^{2}\right)$ and chlorophyll content $(1.02 \mathrm{mg} / \mathrm{g})$ was recorded under control. The increase in growth parameters might be due to the application of organic manures along with chemical fertilizer increased the content of organic matter, maintain the nutrients balance and improve the physical and chemical properties of the soil. Application of integrated nutrients in soil resulted in better physical and biological properties of soil in respect of texture, granulation, fertility, porosity, water holding capacity and soil reactions, increased micro flora and fauna which may be helpful to the crop for utilization of nutrients and water absorption. Similar results were earlier found by Nath and Singh (2011) in cauliflower, Kumar et al., 2013 and Abha et al., (2019) in okra

The foliar application of Brassinoides also showed significant difference among the treatments in terms of growth parameters of okra (Table 1). The maximum plant height $(112.58 \mathrm{~cm})$, number of branches/plant (2.50), leaf area $\left(111.97 \mathrm{~cm}^{2}\right)$ and chlorophyll content $(1.52 \mathrm{mg} / \mathrm{g})$ noted with foliar application of Brassinoides at $5 \mathrm{ppm}\left(\mathrm{B}_{1}\right)$ which was statistically at par with application of Brassinoides $10 \mathrm{ppm} \quad\left(\mathrm{B}_{2}\right)$, whereas minimum plant height $(110.23 \mathrm{~cm})$, number of branches/plant (1.86), leaf area $\left(93.96 \mathrm{~cm}^{2}\right)$ and chlorophyll content (1.27 $\mathrm{mg} / \mathrm{g})$ registered with control. It is due to stimulating effect of brassinoides in cell division and cell elongation. Another possible reason might be due to increase secretion of other PGRs in plant body like auxin and gibberalic acid which enhanced vegetative growth due to their synergistic action in plant body which ultimately increased the growth. Similar results were also reported by Bhadala (2017) in vegetable cluster bean and Ola et al., (2018) in broccoli.

Salicylic acid had also exhibited significant effect on growth parameters of okra (Table1). The foliar application of $150 \mathrm{ppm}$ Salicylic acid $\left(\mathrm{S}_{2}\right)$ resulted in maximum plant height $(112.08 \mathrm{~cm})$, number of branches/plant (2.38), leaf area $\left(111.69 \mathrm{~cm}^{2}\right)$ and chlorophyll content $(1.48 \mathrm{mg} / \mathrm{g})$, whereas minimum plant height $(110.98 \mathrm{~cm})$, number of branches/ plant (2.10), leaf area $\left(94.69 \mathrm{~cm}^{2}\right)$ and chlorophyll content $(1.34 \mathrm{mg} / \mathrm{g})$ had been found under control. It is due to higher concentration of salicylic acid enhanced photosynthetic rate and biochemical parameters. Foliar spray of salicylic acid at higher concentration leads to synthesis of more carbohydrate in plants. Chlorophyll pigments viz. Chlorophyll a, b and light harvesting complex which play a key role in light capturing during photosynthesis which increases intensity of light and dark reactions as well as other photosynthetic reactions. Salicylic acid at higher concentration can also stimulate the growth through increasing the activities like antioxidant enzymes, preventing protein loss and enhancing photosynthetic pigment thereby increasing overall growth parameter of the plant. Similar results were also reported by Maniram et al., (2012 a and Pal et al., 2015 in gladiolus, Aashutosh et al., 2019 in chrysanthemum, Mirdad (2015) in broccoli, Meena et al., (2016) in cluster bean and Yadav et al., (2019) in okra. 
Table.1 Effect of integrated nutrients and bio-regulators on plant height, number of branches/plant, leaf area $\left(\mathrm{cm}^{2}\right)$ and chlorophyll content $(\mathrm{mg} / \mathrm{g})$ of Okra

\begin{tabular}{|c|c|c|c|c|}
\hline Treatment & Plant height (cm) & Number of branches/plant & Leaf area $\left(\mathrm{cm}^{2}\right)$ & Chlorophyll content $(\mathrm{mg} / \mathrm{g})$ \\
\hline $\mathbf{R}_{\mathbf{0}}$ & 107.69 & 1.55 & 91.03 & 1.02 \\
\hline $\mathbf{R}_{1}$ & 114.32 & 2.74 & 114.52 & 1.69 \\
\hline $\mathbf{R}_{2}$ & 113.01 & 2.52 & 112.08 & 1.58 \\
\hline SEm \pm & 1.31 & 0.03 & 1.25 & 0.02 \\
\hline $\mathrm{CD}(\mathrm{P}=\mathbf{0 . 0 5})$ & 3.77 & 0.08 & 3.59 & 0.05 \\
\hline $\mathbf{B}_{\mathbf{0}}$ & 110.23 & 1.86 & 93.96 & 1.27 \\
\hline $\mathbf{B}_{1}$ & 112.58 & 2.50 & 111.97 & 1.52 \\
\hline $\mathbf{B}_{2}$ & 112.21 & 2.45 & 111.70 & 1.50 \\
\hline SEm \pm & 1.30 & 0.03 & 1.25 & 0.02 \\
\hline $\mathrm{CD}(\mathrm{P}=0.05)$ & 3.75 & 0.08 & 3.59 & 0.05 \\
\hline $\mathbf{S}_{\mathbf{0}}$ & 110.98 & 2.10 & 94.69 & 1.34 \\
\hline $\mathbf{S}_{1}$ & 111.96 & 2.33 & 111.25 & 1.47 \\
\hline $\mathbf{S}_{2}$ & 112.08 & 2.38 & 111.69 & 1.48 \\
\hline SEm \pm & 1.30 & 0.03 & 1.25 & 0.02 \\
\hline $\mathrm{CD}(\mathrm{P}=\mathbf{0 . 0 5})$ & $* 3.75$ & 0.08 & 3.59 & 0.05 \\
\hline
\end{tabular}


Table.2 Effect of integrated nutrients and bio-regulators on fruit length, fruit diameter $(\mathrm{cm})$, fruit diameter $(\mathrm{cm})$, number of fruits/plant, fruit yield/plant (g), fruit yield/plot $(\mathrm{kg})$ and fruit yield (q/ha) of Okra

\begin{tabular}{|c|c|c|c|c|c|c|}
\hline Treatment & $\begin{array}{l}\text { Fruit length } \\
\qquad(\mathrm{cm})\end{array}$ & $\begin{array}{c}\text { Fruit diameter } \\
(\mathbf{c m})\end{array}$ & $\begin{array}{l}\text { Number of } \\
\text { fruits /plant }\end{array}$ & Fruit yield/plant(g) & $\begin{array}{l}\text { Fruit yield/plot } \\
\text { (kg) }\end{array}$ & Fruit yield (q/ha) \\
\hline $\mathbf{R}_{\mathbf{0}}$ & 7.99 & 1.64 & 19.10 & 102.00 & 2.49 & 56.67 \\
\hline $\mathbf{R}_{1}$ & 11.20 & 2.01 & 22.41 & 195.36 & 4.67 & 108.53 \\
\hline $\mathbf{R}_{\mathbf{2}}$ & 11.47 & 2.14 & 22.92 & 198.62 & 4.75 & 110.34 \\
\hline $\mathrm{SE}(\mathbf{m}) \pm$ & 0.13 & 0.02 & 0.26 & 2.13 & 0.05 & 1.17 \\
\hline $\mathrm{CD}(\mathrm{P}=0.05)$ & 0.36 & 0.07 & 0.74 & 6.11 & 0.15 & 3.35 \\
\hline $\mathbf{B}_{\mathbf{0}}$ & 8.02 & 1.77 & 19.25 & 106.63 & 2.59 & 59.24 \\
\hline $\mathbf{B}_{1}$ & 11.63 & 2.06 & 22.83 & 195.09 & 4.67 & 108.38 \\
\hline $\mathbf{B}_{2}$ & 11.01 & 1.96 & 22.35 & 194.26 & 4.65 & 107.92 \\
\hline $\mathrm{SE}(\mathbf{m}) \pm$ & 0.13 & 0.02 & 0.26 & 2.13 & 0.05 & 1.17 \\
\hline $\mathrm{CD}(\mathrm{P}=0.05)$ & 0.36 & 0.07 & 0.74 & 6.11 & 0.15 & 3.35 \\
\hline $\mathbf{S}_{\mathbf{0}}$ & 8.95 & 1.89 & 19.97 & 108.23 & 2.60 & 60.13 \\
\hline $\mathbf{S}_{1}$ & 10.77 & 1.93 & 22.16 & 193.56 & 4.65 & 107.53 \\
\hline $\mathbf{S}_{\mathbf{2}}$ & 10.94 & 1.97 & 22.30 & 194.19 & 4.66 & 107.88 \\
\hline $\mathrm{SE}(\mathbf{m}) \pm$ & 0.13 & 0.02 & 0.26 & 2.13 & 0.05 & 1.17 \\
\hline $\mathrm{CD}(\mathrm{P}=\mathbf{0 . 0 5})$ & 0.36 & 0.07 & 0.74 & 6.11 & 0.15 & 3.35 \\
\hline
\end{tabular}


Table.3 Interaction effect of integrated nutrients with bio-regulators on fruit parameters of okra

\begin{tabular}{|c|c|c|c|c|c|c|}
\hline Treatment & $\begin{array}{l}\text { Fruit length } \\
(\mathrm{cm})\end{array}$ & $\begin{array}{l}\text { Fruit diameter } \\
\qquad(\mathrm{cm})\end{array}$ & $\begin{array}{c}\text { Number of fruits } \\
\text { /plant }\end{array}$ & $\begin{array}{l}\text { Fruit yield/plant } \\
\text { (g) }\end{array}$ & Fruit yield/plot (kg) & Fruit yield (q/ha) \\
\hline $\mathbf{R}_{0} \mathbf{B}_{0} \mathrm{~S}_{0}$ & 5.49 & 1.47 & 15.92 & 43.07 & 1.07 & 23.93 \\
\hline $\mathbf{R}_{0} \mathbf{B}_{0} S_{1}$ & 6.61 & 1.50 & 17.66 & 77.02 & 1.91 & 42.79 \\
\hline $\mathbf{R}_{0} \mathbf{B}_{0} S_{2}$ & 6.71 & 1.54 & 17.78 & 77.27 & 1.91 & 42.93 \\
\hline $\mathbf{R}_{0} \mathbf{B}_{1} \mathbf{S}_{0}$ & 7.96 & 1.71 & 18.88 & 78.79 & 1.92 & 43.78 \\
\hline $\mathbf{R}_{0} \mathbf{B}_{1} \mathrm{~S}_{1}$ & 9.58 & 1.75 & 20.95 & 140.92 & 3.43 & 78.29 \\
\hline $\mathbf{R}_{0} \mathbf{B}_{1} \mathbf{S}_{2}$ & 9.73 & 1.79 & 21.08 & 141.38 & 3.44 & 78.54 \\
\hline $\mathbf{R}_{0} \mathbf{B}_{2} \mathbf{S}_{0}$ & 7.54 & 1.63 & 18.48 & 78.46 & 1.91 & 43.59 \\
\hline $\mathbf{R}_{0} \mathbf{B}_{2} \mathrm{~S}_{1}$ & 9.07 & 1.67 & 20.51 & 140.32 & 3.42 & 77.96 \\
\hline $\mathbf{R}_{0} \mathbf{B}_{2} \mathbf{S}_{2}$ & 9.21 & 1.70 & 20.64 & 140.77 & 3.43 & 78.21 \\
\hline $\mathbf{R}_{1} \mathbf{B}_{0} \mathbf{S}_{0}$ & 7.70 & 1.81 & 18.68 & 82.49 & 2.00 & 45.83 \\
\hline $\mathbf{R}_{1} \mathbf{B}_{0} \mathrm{~S}_{1}$ & 9.26 & 1.84 & 20.73 & 147.52 & 3.57 & 81.95 \\
\hline $\mathbf{R}_{1} \mathbf{B}_{0} \mathbf{S}_{2}$ & 9.41 & 1.88 & 20.86 & 148.00 & 3.58 & 82.22 \\
\hline $\mathbf{R}_{1} \mathbf{B}_{1} \mathbf{S}_{0}$ & 11.16 & 2.10 & 22.15 & 150.92 & 3.60 & 83.84 \\
\hline $\mathbf{R}_{1} \mathbf{B}_{1} \mathbf{S}_{1}$ & 13.43 & 2.15 & 24.58 & 269.90 & 6.43 & 149.93 \\
\hline $\mathbf{R}_{1} \mathbf{B}_{1} \mathbf{S}_{2}$ & 13.64 & 2.19 & 24.74 & 270.78 & 6.44 & 150.42 \\
\hline $\mathbf{R}_{1} \mathbf{B}_{2} \mathbf{S}_{0}$ & 10.57 & 2.00 & 21.69 & 150.27 & 3.58 & 83.49 \\
\hline $\mathbf{R}_{1} \mathbf{B}_{2} \mathbf{S}_{1}$ & 12.72 & 2.04 & 24.06 & 268.75 & 6.40 & 149.30 \\
\hline $\mathbf{R}_{1} \mathbf{B}_{2} \mathbf{S}_{2}$ & 12.92 & 2.08 & 24.22 & 269.62 & 6.42 & 149.78 \\
\hline $\mathbf{R}_{2} \mathbf{B}_{0} \mathbf{S}_{0}$ & 7.88 & 1.92 & 19.10 & 83.86 & 2.03 & 46.59 \\
\hline $\mathbf{R}_{2} \mathbf{B}_{0} \mathbf{S}_{1}$ & 9.49 & 1.96 & 21.20 & 149.98 & 3.63 & 83.32 \\
\hline $\mathbf{R}_{2} \mathbf{B}_{0} \mathbf{S}_{2}$ & 9.64 & 2.00 & 21.33 & 150.47 & 3.64 & 83.59 \\
\hline $\mathbf{R}_{2} \mathbf{B}_{1} \mathbf{S}_{0}$ & 11.43 & 2.24 & 22.66 & 153.43 & 3.66 & 85.24 \\
\hline $\mathbf{R}_{2} \mathbf{B}_{1} \mathbf{S}_{1}$ & 13.75 & 2.28 & 25.14 & 274.40 & 6.54 & 152.44 \\
\hline $\mathbf{R}_{2} \mathbf{B}_{1} \mathbf{S}_{2}$ & 13.97 & 2.33 & 25.30 & 275.30 & 6.55 & 152.93 \\
\hline $\mathbf{R}_{2} \mathbf{B}_{2} \mathbf{S}_{0}$ & 10.82 & 2.13 & 22.18 & 152.78 & 3.64 & 84.88 \\
\hline $\mathbf{R}_{2} \mathbf{B}_{2} \mathbf{S}_{1}$ & 13.02 & 2.17 & 24.61 & 273.23 & 6.51 & 151.79 \\
\hline $\mathbf{R}_{2} \mathbf{B}_{2} \mathbf{S}_{2}$ & 13.23 & 2.22 & 24.77 & 274.12 & 6.53 & 152.28 \\
\hline $\mathrm{SE}(\mathrm{m}) \pm$ & 0.38 & 0.07 & 0.772 & 6.38 & 0.153 & 3.49 \\
\hline $\mathrm{CD}$ at $5 \%$ & 1.08 & 0.20 & 2.2 & 18.34 & 0.44 & 10.047 \\
\hline
\end{tabular}


Data presented in (Table -2) showed that application of different integrated nutrient sources and foliar application of bioregulators had significant effect on yield parameters of okra. Plant receiving 50\% RDF and 12.0 tonne $\mathrm{FYM} / \mathrm{ha}\left(\mathrm{R}_{2}\right)$ showed maximum fruit length $(11.47 \mathrm{~cm})$, fruit diameter $(2.14 \mathrm{~cm})$, number of fruit per plant (22.92), fruit yield per plant (198.62 g), fruit yield per plot $(4.75 \mathrm{~kg})$ and fruit yield $(110.34$ $\mathrm{q} / \mathrm{ha})$ whereas, control $\left(\mathrm{R}_{0}\right)$ produced minimum fruit length $(7.99 \mathrm{~cm})$, fruit diameter $(1.64 \mathrm{~cm})$, number of fruits per plant (19.10), fruit yield per plant (102.00 g), fruit yield per plot $(2.49 \mathrm{~kg})$ and fruit yield $(56.67$ $\mathrm{q} / \mathrm{ha}$ ). It might be due to integrated approaches of fertilizers and manures which may help to improve the availability of nutrients to the plants. Plant nutrient uptake increased cellular activity of plant like multiplication and elongation while, phosphorous would have increased all yield attributes by increase the plant tissues. The results are in line with the findings of Sharma et al., (2018) in broccoli and Singh et al., (2020) in okra.

Plant sprayed with brassinoides showed various effects on yield of okra (Table-2). The maximum fruit length $(11.63 \mathrm{~cm})$, fruit diameter $(2.06 \mathrm{~cm})$, number of fruits per plant (22.83), fruit yield per plant (195.09 g), fruit yield per plot $(4.67 \mathrm{~kg})$ and fruit yield $(108.38$ $\mathrm{q} / \mathrm{ha}$ ) noted on plants sprayed with $5 \mathrm{ppm}\left(\mathrm{B}_{1}\right)$ brassinoides which was significantly at par with application of $10 \mathrm{ppm}\left(\mathrm{B}_{2}\right)$ brassinoides however, minimum fruit length $(8.02 \mathrm{~cm})$, fruit diameter $(1.77 \mathrm{~cm})$, number of fruits per plant (19.25, fruit yield per plant (106.63 g), fruit yield per plot $(2.59 \mathrm{~kg})$ and fruit yield $(59.24 \mathrm{q} / \mathrm{ha})$ produced under control $\left(\mathrm{B}_{0}\right)$. It could be attributed to the stimulatory effect of brassinoides on cell expansion and development of plant with better utilization of resources. Application of brassiniodes increased the total biomass and then might have resulted in an increase in assimilate transport from source to sink and their ultimate conversion into final reserved food which may help to improve the yield. Similar results were also reported by Matwa et al., (2017) in green gram and Netwal (2018) in Indian bean.

Foliar application of salicylic acid also influenced the yield of okra (Table-2. Foliar application of $150 \mathrm{ppm}$ salicylic acid resulted in maximum fruit length $(10.94 \mathrm{~cm})$, fruit diameter $(1.97 \mathrm{~cm})$, number of fruits per plant (22.30), fruit yield per plant (194.19 g), fruit yield per plot $(4.66 \mathrm{~kg})$ and fruit yield (107.88 $\mathrm{q} / \mathrm{ha}$ ) which was statistically at par with foliar application of $100 \mathrm{ppm}$ salicylic acid $\left(\mathrm{S}_{1}\right)$, while control plants $\left(\mathrm{S}_{0}\right)$ produced minimum fruit length $(8.95 \mathrm{~cm})$, fruit diameter $(1.89$ $\mathrm{cm}$ ), number of fruits per plant (19.97), fruit yield per plant $(108.23 \mathrm{~g})$, fruit yield per plot $(2.60 \mathrm{~kg})$ and fruit yield (60.13 q/ha). The foliar application of salicylic acid play a vital role in plant growth and development, photosynthetic reactions, transpiration, ion uptake, transport and protein synthesis. Salicylic acid also induced in leaf anatomy and chloroplast structure in plants and regulates source sink relationship ultimately increased the yield Gharib (2007) and Bartoli et al., (1999). Salicylic acid increased immunity of plant against biotic and abiotic stresses and it also increased the supply of nutrients to the plants and improved tolerance of plants. The present results are in line with Kumar et al., (2014) on cowpea, Mirdad (2015) in broccoli, Kazmi (2015) in tomato, Rady et al., (2015) in moringa, Netwal (2018) in Indian bean and Yadav et al., (2019) in okra.

The combination of treatments also influenced the yield of okra (Table-3). The maximum fruit length $(13.97 \mathrm{~cm})$, fruit diameter $(2.33 \mathrm{~cm})$, number of fruits per plant (25.30), fruit yield per plant (275.30 g), fruit 
yield per plot $(6.55 \mathrm{~kg})$ and fruit yield $(152.93$ q/ha) had been registered with the treatment combination of 50\% RDF and 12.0 tonne FYM/ha+ Brassinoides @ 5ppm+Salicylic acid @ 150 ppm $\left(\mathrm{R}_{2} \mathrm{~B}_{1} \mathrm{~S}_{2}\right)$ which was statistically at par with treatment combinations viz: $R_{2} B_{1} S_{1}, R_{1} B_{1} S_{2}, R_{1} B_{1} S_{1}$, $\mathrm{R}_{2} \mathrm{~B}_{2} \mathrm{~S}_{2}$ etc. whereas, the minimum fruit length $(5.49 \mathrm{~cm})$, fruit diameter $(1.47 \mathrm{~cm})$, number of fruits per plant (15.92), fruit yield per plant $(43.07 \mathrm{~g})$, fruit yield per plot $(1.07$ $\mathrm{kg})$ and fruit yield $(23.93 \mathrm{q} / \mathrm{ha})$ registered with control combination $\left(\mathrm{R}_{0} \mathrm{~B}_{0} \mathrm{~S}_{0}\right)$. It might be due to synergistic effect of integrated sources of nutrients with bio-regulators on above treatment combinations. Similar results were also reported by Ola et al., (2018) in broccoli.

On the basis of results obtained from the present investigation, it may be concluded that integrated application of nutrients viz. 50 per cent RDF through inorganic fertilizer, $12.0 \mathrm{t} / \mathrm{ha}$ FYM and foliar spray of brassinoides@5 ppm and salicylic acid @ $150 \mathrm{ppm}$ as bio-regulators was found most suitable in terms of yield parameters of okra. However, nutrient supplied with 75 per cent RDF through inorganic fertilizer and $6.0 \mathrm{t} / \mathrm{ha}$ FYM, foliar spray of brassinoides $5 \mathrm{ppm}$ and salicylic acid $150 \mathrm{ppm}$ showed better performance in regarding the vegetative growth of okra.

\section{References}

Abha, R., Meena, M. L., Singh, R. and Mandal, R. K. (2019). Effect of various organic manures on growth and yield of okra (Abelmoschus esculentus (L.) Moench). Journal of Pharmacognosy and Phytochemistry, 8(6): 1203-1205.

Bartoli, C.G., Simontacchi, M., Tamussi, E. and Beltrano, J. (1999). Drought and watering dependent oxidative stress: effect on antioxidant content in Triticum aestivum L. leaves. Journal of Experimental Botany, 50(322): 375383.

Bhadala, K. (2017). Effect of bio-regulators and bio-fertilizers on growth, yield and quality of vegetable cluster bean [Cyamopsis tetragonoloba (L.) Taub]. M.Sc. (Ag.) Thesis submitted to S.K.N. Agriculture University, Jobner.

Chavan, J. K., Dalvi, U. and Chavan U. D. (2007). Isolation of lady's finger (okra) stem mucilage as clarificant in jaggery preparation. Journal of Food Science and Technology, 44(1): 59-61

Doares, S. H., J. Narvaer, A. Conconi, and Ryan, A. C. (1995). Salicylic acid inhibits synthesis of proteinase inhibitors in tomato leaves induced by systemin and jasmonic Acid. Plant Physiol. 108:1741-1746

El-Tayeb, M.A. (2005). Response of barley grains to the interactive effect of salinity and salicylic acid. Plant Growth Regulation, 45:215-224.

Gharib, F.A.E. (2007). Effect of salicylic acid on growth, metabolic activities and oil content of basil and marjoram. International Journal of Agriculture and Biology, 9(2): 294-301.

Gomez, K.A. and Gomez, A.A. (1983). Statistical Procedure for Agriculture Research, 2nd ed., John Wiley and Sons, Inc. New York, pp. 357-427.

Hayat, Q., Hayat, S., Irfan, M. and Ahmad, A. (2010). Effect of exogenous salicylic acid under changing environment: A review. Environmental and Exprimental Botany 68(2):14- 25.

Hernandez, G.G. and Vargas, V.M.L. (1997). Effect of acetyl salicylic acid on secondary metabolism of Catharantus roseus suspension culture. Plant Cell Rep., 16(5):287-290

Huang, Y.F., C.T. Chen, and Kao, C.H. (2004). Salicylic acid inhibits the 
biosynthesis of ethylene in detached rice leaves. Plant Growth Regul., 12(1-2):79-82

Kazemi, M. (2014). Foliar application of salicylic acid and methyl jasmonate on yield, yield components and chemical properties of tomato. Jordan Journal of Agricultural Sciences, 10(4): 71-76.

Khodary, S.E.A. (2004). Effect of salicylic acid on the growth, photosynthesis and carbohydrate metabolism in saltstressed maize plants. J. Agric. Biol., 6: $5-8$

Kumar, T., Kumar, M., Singh, M.K., Kumar, V., Kumar, A. Kumar, S., and Singh, B. (2013) Impact of integrated nutrient management on growth and economic yield of Okra. (Abelmoschus esculentus (L.) Moench). Annals of Horticulture 6(1): 107-114

Kumar, M. (2014). Effect of different sources of nutrients on growth and flowering in tuberose (Polianthes tuberosa 1.) cv. "Vaibhav". Progressive Research 9 (Special): 872-875.

Kumar, M. (2014a) Effect of different sources of nutrients on growth and flowering in gladiolus (Gladiolus hybridus Hort.) cv. Peater Pears. Annals of Horticulture, 7(2): 154-158

Kumar, M. (2015) Impact of different sources of nutrients on growth and flowering in chrysanthemum (Chrysanthemum morifolium ramat.) cv Yellow Gold. Journal of Plant Development Sciences 7(1): 49-53

Kumar, A., Singh, B., Kumar, D., Kumar, P., Kumar, T., Kumar, S. and Goswami, A. (2014). Effect of balanced fertilizer and planting techniques on growth and yield of garlic (Allium Sativum L.). Annals of Horticulture, 7(2): 123-128.

Kumar, M. and Chaudhary, V. (2018). Effect of integrated sources of nutrients on growth, flowering, yield and soil quality of floricultural crops: A review. Int. J. Curr. Microbiol. App. Sci. 7(03): 2373-2404

Kumar, M., Chaudhary, V., Naresh, R.K., Maurya, O.P. and Pal, S.L. (2018) Does integrated sources of nutrients enhance growth, yield, quality and soil fertility of vegetable crops?. Int. J. Curr. Microbiol. App. Sci, 7(6): 125155

Maniram, Pal, V., Singh, M.K. and Kumar, M. (2012). Response of different spacing and salicylic acid levels on growth and flowering of gladiolus (Gladiolus grandiflorus L). Hortflora Research Spectrum, 1(3): 270-273

Maniram, Kumar, M., Malik, S., Singh, M.K. and Pal, V. (2012) Impact of Spacing, doses of Vermi- Compost and foliar application Salicylic Acid on Growth and Flowering of Gladiolus (Gladiolus Grandiflorus L.) Cv. "White Prosperity" Annals of Horticulture 5(2): 272-279

Matwa, D., Rao, K. P., Dhewa, J. S. and Rajveer (2017). Effect of plant growth regulators and micronutrients on flowering and yield parameters of green gram (Vigna radiata L.). International Journal Current Microbiology Applied Science, 6(4): 2350-2356.

Meena, H., Meena, R. S., Rajput, B. S. and Kumar, S. (2016). Response of bioregulators to morphology and yield of cluster bean [Cyamopsis tetragonoloba (L.) Taub.] under different sowing environments. Journal of Applied and Natural Science, 8(2): 715-718.

Mirdad, Z. M. (2015). Effect of $\mathrm{K}^{+}$and salicylic acid on broccoli (Brassica oleracea var.Italica) plants grown under saline water irrigation. Journal of Agricultural Science, 6(10): 57-64.

Mohit, Kumar, M., Singh, M.K., Singh, S.P. and Naresh, R.K. (2019). Effect of 
integrated use of organic and inorganic sources of nutrients on growth, yield quality and profitability of tomato (Lycopersicon esculentum Mill.) var. Pusa Rohini. Int. J. Agricult. Stat. Sci., 15(1): 57-66

Nath, G. and Singh, K. (2011). Role of vermicompost for the productivity of cauliflower (Brassica oleracea) and biopesticides against nematode (Meloidogyne incognita). World Applied Sciences Journal, 12(10): 1676-1684

Netwal, M. (2018). Effect of bio-regulators and plant growth promoting bacteria (PGPB) on growth, yield and quality of indian bean (Lablab purpureus $\mathrm{L}$. var. typicus). M.Sc. (Ag.) Thesis submitted to S.K.N. Agriculture University, Jobner.

Ola, A. L., Bairwa, L. N., Singh, B. and Jakher, R. K. (2019). Effect of integrated nutrient management and bio-regulators on quality attributed of broccoli (Brassica oleracea L. Italica Plenck). International Journal of Current Microbiology and Applied Sciences, 8(3): 221-227.

Ola, A. (2018). Effect of integrated nutrient management and bio-regulators on growth, yield and quality of sprouting broccoli [Brassica oleracea (L.) var. italica Plenck]. Ph.D. (Ag.) Thesis submitted to S.K.N. Agriculture University, Jobner.

Pal, V., Maniram and Kumar, M (2015) Effect of various levels of spacing and salicylic acid treatment on vegetative growth and flowering of gladiolus (gladiolus grandiflora 1.) cv. White prosperity. South Asian J. Food Technol. Environ. 1(1): 101-104.

Phonglosa, A., Bhattacharyya, K., Ray, K., Mandal, J., Pari, A., Banerjee, H.,Chattopadhyay, A., 2015. Integrated nutrient management for okra in aninceptisol of eastern India and yield modeling through artificial neuralnetwork. Sci. Hortic. 187, 1-9.

Popova, L., Pancheva, T. and Uzunova, A. (1997). Salicylc acid properties, biosynthesis and physiological role. Bulg. J. Plant Physiol., 23(1-2) 85-93.

Priyanshu, A.B., Singh, M.K., Malik, S., Kumar, M., Kumar, V., Tripathi, S.K. and Shahi, U.P. (2019). Effect of integrated nutrient management on growth characters of garlic (Allium sativum L.) cv. Yamuna Safed-3. Prog. Agric., 19 (2): 242-246

Rademacher, W. (2016). Chemical regulators of gibberellin status and their application in plant production. Annual Plant Reviews, 49:359-403.

Rady, M. M., Mohamed, G. F., Abdalla, A. M. and Ahmed, Y. H. M. (2015). Integrated application of salicylic acid and Moringa oleifera leaf extract alleviates the salt-induced adverse effects in common bean plants. International Journal of Agricultural Technology, 11(7): 1595-1614.

Rao, T. S. S. and Sankar, C. R. (2001). Effect of organic manures on growth and yield of Brinjal. South Indian Horticulture, 49: 288-291.

Sharma, C., Kang, B. S., Kaur, R., Singh, S. K. and Aulakh, K. (2018). Effect of integrated nutrient management on growth, yield and quality of broccoli (Brassica oleracea L. var. italica). International Journal of Chemical Studies, 6(2): 1296-1300.

Singh, B. and Usha, K. (2003). Salicylic acid induced physiological and biochemical changes in wheat seedlings under water stress. Plant Growth Regul., 23:366-370.

Singh R., Kumar M., Raj, S. and Kumar, S. (2013). Effect of Integrated Nutrient Management (INM) on growth and flowering in gladiolus (Gladiolus 
grandiflorus L.) cv. "White Prosperity. Annals of Horticulture 6 (2): 242-251

Singh R., Kumar M., Raj, S. and Kumar, S. (2014). Flowering and corm production in gladiolus (Gladiolus grandiflorus L.) cv. "White Prosperity" as influenced by Integrated Nutrient Management (INM). Annals of Horticulture. 7 (1): 36-42

Singh, P, Prakash, S, Kumar, M., Kumar, S and Singh, M.K. (2015). Effect of integrated nutrient management (INM) on growth, flowering and yield of marigold (Tagetes erecta L), Pusa Basanti. Annals of Horticulture, 8(1): 73-80.

Singh, J., Singh, M.K., Kumar, M., Kumar, V., Singh, K.P. and Omid, A.O. (2018) Effect of integrated nutrient management on growth, flowering and yield attributes of cucumber (Cucumis sativus L.). International Journal of Chemical Studies, 6(4): 567-572

Singh, A., Prasad, V. M., Srivastava, R. and Bahadur, V. (2020). Effect of integrated nutrient management on growth, yield and quality of okra (Abelmoschus esculentus L. Moench) cv. Kashi Pragati. Journal of Pharmacognosy and Phytochemistry, 9(2): 1978-1984.

Tiwari, H., Kumar, M. and Naresh, R.K. (2018) Effect of nutrient management and gibberellic acid on growth, flowering and nutrients availability in post-harvested soil of Marigold (Tagetes erecta L.) cv. Pusa Narangi Gainda. International Journal of Chemical Studies; 6(4): 510-514

Tiwari, H., Kumar, M., Naresh, R.K., Singh, M.K., Malik, S., Singh, S.P. and Chaudhary, V. (2018a). Effect of organic and inorganic fertilizers with foliar application of gibberellic acid on productivity, profitability and soil health of marigold (Tagetes erecta L.) cv. Pusa Narangi Gainda. Int. J. Agricult. Stat. Sci., 14 (2): 575-585

Vardhini, B., Anuradha, S. and Rao, S. R. (2006). Brassinosteroids - New class of plant hormone with the potential to improve crop productivity. Indian Journal of Plant Physiology, 11(1): 112.

Varmudy, V. (2011). Marking survey need to boost okra exports. Department of economics, Vivekananda College, Puttur, Karnataka, India.

Yadav, S. C., Choudhry, M. R., Ujjainiya, P. and Yadav, B. L. (2019). Influence of plant growth substances and biofertilizers on physiological parameters of vegetable cowpea (Vigna unguiculata (L.) Walp). International Journal of Current Microbiology and Applied Sciences, 8(8): 812-818.

Yildirim, E., E. Turan, and Guvenc, M. (2008). Effect of foliar salicylic acid application on growth, chlorophyll and mineral content of cucumber grown under salt stress. J. Plant Nutr., 31:593-612.

\section{How to cite this article:}

Khushboo Sharma, Archi Gupta, Mukesh Kumar, Manoj Kumar Singh, Sunil Malik, Bijendra Singh, S. P. Singh and Veena Chaudhary. 2020. Effect of Integrated Nutrient Management and Foliar Spray of Bioregulators on Growth and Yield of Okra. Int.J.Curr.Microbiol.App.Sci. 9(12): 344-354. doi: https://doi.org/10.20546/ijcmas.2020.912.044 